Available Online at http://journal.unismuh.ac.id/index.php/otoritas

Otoritas : Jurnal Ilmu Pemerintahan, 7 (2), October 2017, 75-83

\title{
Understanding the Impact of the Counter-Terror Agenda on Humanitarian Action
}

\author{
Francesco Bruno*) \\ Peace and Conflict Studies, Humanitarian and Conflict Response Institute (HCRI), \\ University of Manchester, Oxford Rd, Manchester M13 9PL, United Kingdom.
}

Received: 4 August 2017; Revised: 23 September 2017; Accepted: 20 October 2017

\begin{abstract}
The paper reflects on the impact of the counter-terror agenda on humanitarian actions. It explores the socio-political and legal implications and constraints that Non-Governmental Organisations incur when managing humanitarian projects in critical environments such as Somalia where, an important famine stroke in 2011 as consequence of the counter-terror agenda, insecurity and politicization. In the case of Somalia, Al-Shabaab, a group well-known to the international authority as affiliated to Al-Qaeda was in charge of the area in which the famine stroke. The dilemma to consider in this paper is paper is related to the binomial situation between the people in need and the counterterrorism strategy against Al-Shabaab. The paper outlines three issues that the humanitarian actors incur, namely structural, operational and of internal nature. These three issues undermines the relationship between the Humanitarian actors and the donors as well as between humanitarian actors and their recipients. At the end, the relationship continues to be highly controversial.
\end{abstract}

Keywords: Counter Terror; Humanitarian; binomial situation

How to Cite: Bruno, F. (2017). Understanding the Impact of the Counter-Terror Agenda on Humanitarian Action. Otoritas : Jurnal Ilmu Pemerintahan, 7(2), 75-83.

Permalink/DOI: https://doi.org/10.26618/ojip.v7i2.815

${ }^{*}$ Corresponding Author.

E-Mail : mrfrabruno@gmail.com

Copyright (C) 2017, Otoritas : Jurnal Ilmu Pemerintahan, ISSN: 2088-3706 (Print), ISSN: 2502-9320 (Online) 
Available Online at http://journal.unismuh.ac.id/index.php/otoritas

Otoritas : Jurnal Ilmu Pemerintahan, 7 (2), October 2017, 76

\section{INTRODUCTION}

This paper will reflect on an important aspect of the Humanitarian action in contested environments. Specifically, the impact of counter-terror legislation created to avoid material support to Foreign Terrorist Organizations(FTOs). These legislations have been made to avoid that FTOs are able to acquire material of any kind to support their subversive or destructive activities of terrorism. Consequently, the situation becomes more complex when considering the areas in which these organizations act. Specifically, the example of Somalia is exemplary to outline the blurring line between terrorist groups and civilians and how often terrorist organizations control humanitarian access to areas where people are in need. In this sense, the importance of exploring this aspect is essential to point out how counter-terror agenda creates substantial issues for humanitarian actors to access such areas.

The impact of the counter-terror agenda on humanitarian actions and will be using examples from the case study of Somalia. The counter-terror agenda refers to the profound effect that the September 11, 2001 terror attack has had on the United States' foreign policy, and how it has changed the landscape in which humanitarian agencies have acted and adapted. Specifically, the impact of counter-terrorism laws have undermined the relationship between humanitarian agencies and their donors, as well as their recipients, resulting in an environment in which upholding the principles of neutrality, impartiality and independence have become more complicated. In this sense, the use of the case study of Somalia is propaedeutic to explaining the difficulties that counter-terror legislation has applied to humanitarian actors and, consequently, to their actions. In this context, the famine in 2011 has largely been caused by an environment in which counter-terror legis- lation, politicization of aid and insecurity have forced multiple international humanitarian actors to leave the country, including the World Food Program (WFP) which officially withdrew from Somalia in 2010 on the premises that the shipped aid was being redirected and sold for terrorism purposes against Western targets. This paper is divided into two parts; the first highlights the consequences of 9/11 on humanitarian law and how the approvals of counter-terror laws and policies have deeply compromised not only the environment in which humanitarian organizations work but also the principles of neutrality, impartiality and independence. The second discusses the implication of counter-terror laws on three main levels of the humanitarian work, namely: structural, internal and operational and address how such implications have constrained the humanitarian work in Somalia.

\section{RESEARCH METHODS}

The paper has been written on the basis of current primary and secondary sources that address the political and legal constrains of humanitarian agencies in contested areas such as Somalia. The paper has used reports from multiple $\mathrm{Hu}-$ manitarian sources such as the International Committee of the Red Cross to point out the impact of Counter-terrorism laws over humanitarian work. It has been used to point out specific restrictions and bans imposed to avoid that humanitarian aid is diverted towards alternative ends.

In this sense, the use of reports from multiple humanitarian institutes have outlined the pressure imposed by statutes to humanitarian actors. Specifically, the use of humanitarian reports has been important to understand a more practical prospective due to the direct presence on the ground of humanitarian personnel or their direct involvement with the Somali people as well as their presence during the negotiations with US 
officials. The paper has also used a series of Legal sources specifically from the US government to point out the material restrictions on humanitarian agencies in contested environments such as Somalia.

In this sense, the use of resources from the Office of Counterterrorism of the United States is propaedeutic to the role of the legal framework as a tool to pressure the humanitarian agencies. The paper has also focused on the situation in Somalia through the use of a series of reports from World Food Program, Global Food Security and development-related journals to discuss the practical implications of the counter-terrorism policies in Somalia.

\section{RESULT AND DISCUSSION}

The paper outlines three main issues with counter-terrorism legislation on humanitarian action. These issues are of structural, operational and internal nature. First, structural issues have mined the relationship between humanitarian actors and their donors, particularly with the United States. This has been the case for the WFP withdrawal from SouthCentral Somalia.

Second, the operational issues, these have outlined the difficulty of applying counter-terrorism legislation to humanitarian actors in contested areas and how it can affect the operability of NGOs and international organizations; specifically, this paper demonstrates how counterterrorism legislation has been too rigid to deal with Al-Shabaab's obstructionist policies. Al-Shabaab has been able to impose payment of fees and taxes on humanitarian actors causing legal issues for potentially infringing laws that prohibit material support for FTOs.

Third, on the internal issue, lack of coordination and transparent discussions among humanitarian partners and international organizations have undermined the way humanitarian actors can work in a high-risks and contested environemnt in which they will need to deal with supplying local people with humanitarian relief projects, but also with an armed FTO that is openly supporting Al-Qaeda and its mission against the Westn.

This has therefore removed any opportunity to discuss the lack of coordination in contested areas and direct the projects more accurately and with a direct management policy. This has consequently caused the lack of open discussions to address the constant scarcity of food that fuelled the 2011 famine in the country. Put it bluntly, the responsibilities in addressing insecurity, aid diversion and humanitarian delivery of projects issues have been quietly put aside in order to keep donors and public opinion more favourable to funding them.

The first part of this paper will cover how counter-terrorism laws have become an important aspect to consider when humanitarian actors engage in relief projects in conflict-affected societies. In analysing counter-terror policies, it is therefore essential to firstly define it. Counterterrorism legislation encompass a broad number of topics; in this paper, it refers to the deterrence of and prevention of terrorist acts 'and preventing terrorist groups from accessing resources that support their terrorist acts as well as to prevent people from undertaking so-called preparatory acts of terrorism such as attending terrorist training camps, raising or laundering funds for terrorist activities, and inciting terrorist attacks' (Burniske, Modirzadeh, \& Lewis, 2014).

Since 9/11, states have developed sophisticated domestic and international counter-terrorism laws in order to minimize the material and financial support that terrorist groups can obtain from foreign individuals or countries. There have been 18 multilateral treaties regarding counter-terror laws and one of the most relevant is the 'International Convention for the Suppression of the Financing of 
Available Online at http://journal.unismuh.ac.id/index.php/otoritas

Otoritas : Jurnal Ilmu Pemerintahan, 7 (2), October 2017, 78

Terrorism' (International Convention for the Suppression of the Financing of Terrorism, 2001). This treaty posed the basis upon which no material, financial, support was to be given to foreign terrorist organizations.

It states that any person commits an offence within the meaning of this Convention if that person by any means, directly or indirectly, unlawfully and wilfully, provides or collects funds with the intention that they should be used or in the knowledge that they are to be used, in full or in part, in order to carry out An act which constitutes an offence within the scope of and as defined in one of the treaties listed in the annex; or Any other act intended to cause death or serious bodily injury to a civilian, or to any other person not taking an active part in the hostilities in a situation of armed conflict, when the purpose of such act, by its nature or context, is to intimidate a population, or to compel a government or an international organization to do or to abstain from doing any act (International Convention for the Suppression of the Financing of Terrorism, 2001).

Since 1999, the United Nations Security Council (UNSC) approved two important resolutions in light of the bombing of US embassies in East Africa and the 9/11 attack. These resolutions are UNSCR 1198 and UNSCR 1373. Resolution UNSCR 1373 is therefore important for the purpose of this paper and it requires UN members to 'Prohibit their nationals or any persons and entities within their territories from making any funds, financial assets or economic resources or financial or other related services available, directly or indirectly, or the benefit of persons who commit or attempt to commit or facilitate or participate in the commission of terrorist acts, of entities owned or controlled, directly or indirectly, by such persons and of persons and entities acting on behalf of or at the direction of such persons[.](International Convention for the
Suppression of the Financing of Terrorism, 2001).

From these UNSCR resolutions, the UNSC introduced a number of sanctions regimes that target specific groups worldwide that are seen to be a threat to peace and security. For instance, in relation to Somalia, 'these target specific non-state armed groups, including Al-Shabaab and its associates(under the UN Security Council Resolution 733 of 1992) that despite not being necessarily characterised as counter-terrorism measures, the individuals subject to UN sanctions are often brought within the ambit of national counter-terrorist laws' (Pantuliano, Mackintosh, Elhawary, \& Metcalfe, 2011). In this context, Somalia is currently subjected to arms embargo, travel ban, assets freeze and Charcoal ban that are approved by the UNSC pursuant of UNSCR 75(1992) and 1907(2009) (United Nations Security Council Subsidiary Organs, 2009).

The paper will move now to the specific analysis of the main body of laws that plays an important role in its reflections, namely those of the United States. The choice of this country is based upon the following elements: first, the US is at the forefront of counter-terrorism laws and also directly related to the humanitarian actors as the biggest contributor of humanitarian aid, totalling $\$ 50.1 \mathrm{bn}$ in foreign aid and \$18bn in humanitarian assistance worldwide (Foreign Assistance Budget, 2017). Second, the US code could potentially be one of the most adverse impacts on humanitarian organizations (Pantuliano, Mackintosh, Elhawary, \& Metcalfe, 2011).

In relation to humanitarian assistance, the impact of $9 / 11$ has seen an increase of counter-terror laws within the US penal code due to the approval of the USA PATRIOT Act that broadens the basis upon which material and financial support to foreign terrorist organizations (FTOs) is consolidated; it states that 'any 
property tangible or intangible, or service, including currency or monetary instruments or financial security, financial services, lodging, training, expert advice or assistance, safe house, false documentation or identification, communication equipment, facilities, weapons, lethal substances, explosives, personnel (1 or more individuals who may be or include oneself), and transportation, except medicine or religious materials' (Doyle, 2010).

In the light of the USA PATRIOT Act, the FTOs that are covered by the ban are designated and 'chosen by the Secretary of State, as foreign organisations which engage in terrorism and threaten the security of the US or its nationals' (Office of the Coordinator for Counterterrorism Foreign Terrorist Organizations, 1999). In addition to the Patriotic Act, the Executive Order 13224 signed by President Bush in the aftermath of $9 / 11$ allows the Department of the Treasury's Office of Foreign Assets Control (OFAC) to 'block entities, freeze assets, place individuals on the 'Special Designated Nationals' list (SDNs) and identifies 'Specially Designated Global Terrorists' (SDGTs) as well as prohibits the export and donations of products designated to relieve human suffering, specifically food, clothing and medicine"(Modirzadeh, Dustin, \& Bruderlein, 2011). All these laws have therefore put pressure on humanitarian actors and have compromised how they uphold the principles of neutrality, impartiality and independence.

The counter-terrorism laws analysed above have therefore imposed strict rules and regulations for humanitarian agencies in funding agreements. Donors have addressed their national counterterrorism laws through the creation of broad risk-management schemes with relevant guidelines that nongovernmental organizations have to follow. These schemes insist that humanitarian actors are not only aware of procedures to mitigate the risks of funding- diversion, but also donors 'have acknowledged the increased administration and bureaucracy that counter-terrorism measures have imposed on implementing partners' (Mackintosh \& Duplat, 2013).

Specifically, the United States has imposed a series of clauses that ensure that no funds would bring material support to terrorists. Mackintosh and Duplat have reported that "the language employed in these clauses in terms of required action on the part of humanitarian actors includes "best endeavours", 'appropriate steps' and 'to the best of its knowledge' leaving the humanitarian actors to interpret the potential consequences for their liabilities or funding cuts" (Mackintosh \& Duplat (2013).

Accordingly, donors also include clauses that impose requirements on humanitarian actors to report in which manners and where the money was used, and the contacts they acquired on ground. This has therefore raised serious questions regarding the neutrality of their humanitarian action. For instance, Burniske et al. report that the United States Association for International Development (USAID) requires that the implementing partners are not only in compliance with the procedures, but it also requires them to notify the agency if transactions to FTOs have occurred "including a description of any 'safeguards and procedures', including oversight systems, that were in place to help avoid the occurrence of such events" (Burniske, Modirzadeh, \& Dustin, 2014).

In other words, counter-terrorism laws have profoundly influenced riskmanagement and risk-mitigation schemes in high-risk environments. Consequently, these clauses are made to control not only how and where the funds are spent by the implementing partners, but work also in favour of the war on terror through the localization of FTOs and affiliated nonarmed groups within the country or the region. 
This second part of the paper will move on to demonstrate how counterterrorism laws have profoundly impacted the role of humanitarian actors in Somalia. Somalia is an important case study for three reasons. First, 'throughout Somalia's 20-year crisis, the relationship between ongoing, routinized emergency relief operations and episodic but intense stabilisation interventions has been contentious' (Menkhaus, 2010).

Second, it has been the battle ground for an Ethiopian invasion in 2008, a multilateral peacekeeping intervention by African Union Mission in Somalia (AMISOM) and a 'destructive insurgency and counter-insurgency campaign, intensification of Al-Qaeda activities and counter-terrorism actions by the United States and a profound humanitarian crisis' (Menkhaus, 2010). Third, Somalia experiences a unique political context, in which a declared Al-Qaeda affiliatedgroup, Al-Shabaab, was de-facto in control of Central and South Somalia where the 2011 famine struck killing 260,000 people including 133,000 children (Ford, 2017).

In this context, humanitarian agencies found themselves to be working in an environment plagued by security risks for their personnel due to Al-Shabaab attacks and kidnappings. In addition to difficulties in accessing the population in need due to Al-Shabaab's obstructionist policies, and an international community of donors, especially the United States, which was growing impatient of allowing Al-Shabaab to divert part of WFP food assistance to finance terrorism activities in the country.

Counter-terror laws have, therefore, been a direct cause of the 2011 famine. In this sense, there are three levels on which counter-terror law have influenced the way humanitarian actors operate in Somalia and therefore contributed to deteriorate the situation on the ground. First, 'structural, affecting the framework of ac- tion itself and the standard operating procedures for humanitarian organizations; second, operational, affecting programmatic decisions; third, internal, affecting the functioning of and coordination between humanitarian actors' (Mackintosh \& Duplat, 2013).

In terms of structural impact, this refers to the ability of humanitarian actors to uphold the principles of impartiality, neutrality and independence in their engagement with local actors. This has become an important issue not only for humanitarian organizations, but also for donors, financing partners and contractors, specifically the United States, due to aid-diversion towards Al-Shabaab. By 2008, three major food aid operations were operative in the country, namely CARE, WFP and the International Committee for the Red Cross, 'WFP and CARE covered the needs of nearly 2 million people in Somalia' (Maxwell \& Fitzpatrick, 2012).

By the end of 2009, CARE withdrew while WFP was investigating aiddiversion through corrupted local transporters. The UN Monitoring Group's 2010 report detailed specific episodes in which local contractors colluded with $\mathrm{Al}$ Shabaab militia to divert WFP food packages towards black markets in order to buy weapons (Gettleman, 2010).

It also reported that almost $50 \%$ of WFP food packages had been diverted to implementing partners and local militias, and then sold to local markets for profit (UN Monitoring Group, United Nations Official Document, 2010). This situation brought WFP to temporarily, and then permanently, stop the delivery of food packages in Central and South Somalia by the beginning of 2010 .

Menkhaus reports that the US Administration's growing 'legal concern that the provision of any material benefit to a designated terrorist group in contravention of the US Patriot Act and related counter-terrorism legislation would have 
made USAID officials potentially liable of prosecutions under US penal code' (Menkhaus, 2010). In addition, the US Administration was accused of using humanitarian aid for political purposes in order to downgrade Al-Shabaab's capabilities to launch terrorist plots from Somalia through the imposition of harsh conditions to humanitarian partners in exchange for more assurances that food delivery would not be diverted (Gettleman, 2010).

However, humanitarian actors in Somalia were practically unable to provide more assurances "calling southCentral Somalia an 'accountability freezone' in which they possess only modest monitoring capacities" (Menkhaus, 2010). This situation was due to insecurity on the ground that constrained humanitarian NGOs to leave Somalia and control their projects from Nairobi; this has therefore contributed to the so-called 'remote programming' or 'remote management' system which sees humanitarian actors employing local staff to oversee the implementation of their programmes in Somalia (Abild, 2010). This brought NGOs to be unable to perform risk-assessment and project-impact analysis on the communities in Somalia.

In terms of operational issues, these include changes or restrictions on humanitarian actors to access specific areas due to donors' or risk concerns. In this sense, the primary mission for humanitarian actors is to access the population in need and this means finding 'an implicit agreement with the fighting parties' that allows them to operate based on needs and neutrality (Pantuliano, Mackintosh, Elhawary, \& Metcalfe, 2011). However, this has brought some benefits to the fighting parties, as, humanitarian actors are required to pay fees or taxes to the local non-state armed group. In this situation, contractors and partners that have been granted funds and permission by USAID or the State Department to operate in Somalia have to declare the expenditures, through detailed reports, and ask for authorization from OFAC for large amounts in such volatile environments (Pantuliano, Mackintosh, Elhawary, \& Metcalfe, 2011).

In Somalia, humanitarian actors had to compromise with Al-Shabaab, which started to adopt 'puzzling, inconsistent, and self-defeating' policies thereby making it harder for aid agencies to physically access famine-affected areas (Menkhaus, 2012). Moreover, Al-Shabaab imposed an average fee of $\$ 90,000$ per aid agency every six months putting under pressure the humanitarian actors who had to report these large pay cheques to the OFAC and therefore making themselves liable under the US penal system for giving material support to a designated FTO (United Nations Monitoring Groups, 2011). In this situation, NGOs required written assurances from the US government to protect their status on the ground; however, 'humanitarian lawyers concluded that the written assurances offered by the US government did not in fact provide them with adequate legal protection, and that verbal assurances meant nothing' (Acuto, 2014).

In terms of internal issues within humanitarian organizations, counterterrorism legislation increases the bureaucratic burden and lack of transparency among implementing humanitarian partners, with specific focus on a lack of coordination. In the case of Somalia, the aforementioned conditions and specifically the agreements which humanitarian actors were forced to make to access the population in need in Central and South Somalia have created the conditions for lacking a coordinated approach to food relief. For instance, WFP, CARE and ICRC were providing food in three independent operations. This situation was dependent on the fact that no clear and transparent discussion was requested between donors and humanitarian actors. 'Agencies have been reluctant to share information 
at cluster meetings and other coordination fora ' (Pantuliano, Mackintosh, Elhawary, \& Metcalfe, 2011).

In doing so, it has quietly and passively accepted that dealing with AlShabaab required agreements that would be able to create criminal allegations against humanitarian actors. In this situation, what has been extremely important for humanitarian actors is the so-called 'reputational harm' that could potentially provoke deep losses not only in terms of 'how they would address a public relations campaign accusing them of violations of counter-terrorism laws, such as providing support to terrorists with taxpayers funds', but also in terms of the confidence of donors, which would make them more reticent 'to funds actors that may be engaged in allegedly negligent or criminal activity' (Burniske, Modirzadeh, \& Dustin, 2014).

\section{CONCLUSION}

In conclusion, this paper has tried to analyse the impact of counter-terrorism agenda on humanitarian actors. The paper has, firstly, highlighted the primary body of laws that make counter-terrorism an imperative for states worldwide. It has therefore emphasized that $9 / 11$ and the War on Terror have played an important role not only in the case study of Somalia, but also in vehemently impacting the environment in which humanitarian NGOs work.

There have been three main issues with counter-terrorism legislation on humanitarian action: structural, operational and internal. Structural issues have undermined the relationship between humanitarian actors and their donors, particularly with the United States. This has been the case in the WFP withdrawal from South-Central Somalia. Second, on operational issues, it has highlighted how counter-terrorism legislation can affect the areas of operation of humanitarian actors; specifically, this paper has demon- strated how counter-terrorism legislation has been an issue in dealing with AlShabaab's obstructionist policies. Gaining access upon payment of fees or taxes has put the humanitarian actors on the spot for potentially infringing laws that prohibit material support for FTOs.

Third, on the internal issue, lack of coordination and transparent discussions have strongly affected the way humanitarian actors can work in a high-risks context in which they not only need to deal with human suffering, but also with an FTO that is openly supporting Al-Qaeda. This has therefore removed any opportunity to discuss the issues openly in order to coordinate relief projects and address the constant scarcity of food that fuelled the 2011 famine in the country. In this sense, responsibilities in addressing issues have been quietly put aside in order to keep donors and public opinion more favourable to funding them. To conclude, the counter-terror agenda has become profoundly entangled with 'defeating terrorism'.

This has therefore created issues about the way humanitarian actors uphold their values. In addition, counterterrorism legislation does not exempt nor protect humanitarian actors from being prosecuted under criminal law and this remains a major concern for NGOs acting in FTO-controlled areas.

\section{ACKNOWLEDGEMENT}

The author would like to thank director and colleagues in Humanitarian and Conflict Response Institute (HCRI), University of Manchester, UK.

\section{REFERENCES}

Abild, E. (2010). Creating humanitarian space: a case study of Somalia. Refugee Survey Quarterly, 29(3), 67-102.

Acuto, M. (2014). Negotiating Relief: The Politics of Humanitarian Space. 
Available Online at http://journal.unismuh.ac.id/index.php/otoritas

Otoritas : Jurnal Ilmu Pemerintahan, 7 (2), October 2017, 83

Burniske, J., Modirzadeh, N., \& Lewis, D. (2014). Counter-terrorism laws and regulations: What aid agencies need to know. Overseas Development Institute.

Doyle, C. (2010). Terrorist Material Support: An Overview of 18 USC 2339 A and 2339B. DIANE Publishing.

Foreign Assistance Budget. (2017). Retrieved 3 August 2017, from https://www.state.gov/f/budget/

Ford, L. (2013). Somalia Famine in 201012 'Worst in Past 25 years'. The Guardian, 2.

Gettleman, J. (2010). UN Criticizes US Restrictions on Aid to Somalia. New York Times, A8.

International Convention for the Suppression of the Financing of Terrorism. (2001). Retrieved 12 May 2017, from https://www.un.org/ law/cod/finterr.htm

Mackintosh, K., \& Duplat, P. (2013). Study of the impact of donor counterterrorism measures on principled humanitarian action. UN.

Maxwell, D., \& Fitzpatrick, M. (2012). The 2011 Somalia famine: Context, causes, and complications. Global Food Security, 1(1), 5-12.

Menkhaus, K. (2010). Stabilisation and humanitarian access in a collapsed state: the Somali case. Disasters, 34(s3).

Menkhaus, K. (2012). No access: critical bottlenecks in the 2011 Somali famine. Global Food Security, 1(1), 29-35.
Modirzadeh, N. K., Lewis, D. A., \& Bruderlein, C. (2011). Humanitarian engagement under counterterrorism: a conflict of norms and the emerging policy landscape. International Review of the Red Cross, 93(883), 623-647.

Foreign Terrorist Organizations. (1999).htm. Retrieved 16 May 2017, from https://20012009.state.gov/s/ct/rls/rpt/ fto/2682.htm.

Pantuliano, S., Mackintosh, K., \& Elhawary, S. (2011). Counter-terrorism and humanitarian action. Policy.

Security Council Committee pursuant to resolutions 751 (1992) and 1907 (2009) concerning Somalia and Eritrea | United Nations Security Council Subsidiary Organs. (2009). Retrieved 14 May 2017 from https://www.un.org/sc/ suborg/en/ sanctions/751\#Somalia.

United Nations Official Document. (2011). Retrieved 3 August 2017, from http://www.un.org/ga/search/ view_doc.asp? symbol=S/2011/433

United Nations Official Document. (2010). Retrieved 12 May 2017, from http://www.un.org/ga/search/ view_doc.asp? symbol=S/2010/91. 